\title{
Full vector magnetic dating of some pyroclastic rocks associated to the Colima volcano, western Mexico
}

\author{
Gerardo Gifuentes-Nava, Avto Goguitchaichvili, Héctor López-Loera, Miguel Cervantes, \\ Abel Cortés, Leda Sánchez-Bettucci, José Luis Macías, Juan Morales, José Rosas-Elguera
}

\author{
Gerardo Gifuentes-Nava \\ Avto Goguitchaichvili \\ avto@geofisica.unam.mx \\ Miguel Cervantes \\ Juan Morales \\ Laboratorio Interinstitucional de Magnetismo Nat- \\ ural and Servicio Arqueomagnético Nacional, Insti- \\ tuto de Geofisica Unidad Michoacán, Universidad \\ Nacional Autónoma de México - Campus Morelia, \\ 58190, Morelia, México.
}

\section{Gerardo Gifuentes-Nava}

Programa de Posgrado en Ciencias de la Tierra,

Universidad Nacional Autónoma de México, Ciudad Universitaria, s/n, 04510, Ciudad de México,

México.

\section{Héctor López-Loera}

División de Geociencias Aplicadas - IPICYT, Camino a la presa San José 2055, Lomas 4a sección, 78216, San Luis Potosí, S.L.P., México.

\section{Abel Cortés}

Centro Universitario de Estudios e Investigaciones de Vulcanología, Universidad de Colima, Av. Gonzalo de Sandoval \# 444, Villas San Sebastián, C.P. 28045, Colima, México.

\section{Leda Sánchez-Bettucci}

Universidad de la República, Observatorio Geofísico del Uruguay, Iguá 4225, Montevideo, Uruguay.

\section{José Luis Macías}

Instituto de Geofísica Unidad Michoacán, Universidad Nacional Autónoma de México - Campus Morelia, 58190, Morelia, México.

\section{José Rosas-Elguera}

Laboratorio Interinstitucional de Magnetismo Natural, Sede - Universidad de Guadalajara, Av. Juárez No. 976, Edificio de la Rectoría General, piso 11, Colonia Centro, 44100, Guadalajara, Jalisco, México.

\begin{abstract}
A combined rock-magnetic and paleomagnetic researches were carried out on some pyroclastic rocks and pre-Columbian pottery fragments associated to the Colima Volcanic Complex. A full battery of magnetic measurements was performed in order to estimate magnetic mineralogy and to determine both the directions and absolute intensities of the characteristic remanent magnetization. In this paper we report absolute age determination using magnetic dating for two volcanic eruptions associated to the Colima volcano (Volcán de Fuego). The geomagnetic field prediction model SHA. DIF.14K, based on full vector (declination, inclination and absolute paleointensity), was used for first time in pyroclastic flows deposits and intercalated potteries. The results obtained agree reasonably well with available radiometric $\left(\mathrm{C}^{14}\right)$ data, them provide a more accurate age determination of the cooling moment for the lava flows.
\end{abstract}

Keywords: Magnetic dating, Colima volcano, Pyroclastic lava, pre-hispanic pottery, Trans-Mexican Volcanic Belt.

\section{RESUMEN}

Se presentan los resultados de un estudio paleomagnético y de magnetismo de rocas realizado en rocas de flujos piroclásticos y algunos fragmentos de cerámica pre-Colombina asociados al complejo Volcánico de Colima. Con la finalidad de estimar la mineralogía magnética y determinar tanto la magnetización remanente característica, así como la intensidad absoluta, se realizó un conjunto de experimentos y mediciones magnéticas. Se reporta una edad absoluta determinada mediante el fechamiento magnético de dos erupciones volcánicas asociadas al volcán Colima (volcán de Fuego). Esta es la primera vez que el modelo de predicción de campo magnético SHADIF.14K, basado en el vector completo (declinación, inclinación y paleointensidad absoluta), es utilizado en depósitos de flujos piroclásticos intercalados con cerámicas. Los resultados obtenidos concuerdan con las edades radiométricas $\left(C^{14}\right)$ disponibles y constituyen una determinación más precisa de la edad del momento de enfriamiento de los flujos de lava.

Palabras clave: Volcán Colima, fechamiento arqueomagnético, flujos piroclásticos, cerámica prehispánica, Faja Volcánica Transmexicana.
BOL. SOC. GEOL. MEX. 2017

VOL. 69 NO. 3

P. $577-590$ 


\section{Introduction}

The Colima volcano (also known as Volcán de Fuego) is one of the most active volcanoes in Central and North America, it has been characterized by many violent episodes of eruptions and phreatic explosions during the least 500 years. More than 50 eruptions have been documented and 28 have formed small-volume blocks and ash flow deposits (Saucedo et al., 2010). During the same period, the Colima volcano $(\mathrm{CV})$ has generated at least three Plinian eruptions, in 1690, 1818 and 1913 (Luhr and Carmichael, 1990; De la Cruz-Reyna, 1993; Saucedo et al., 2005, 2010) that have produced blocks and ash flow deposits, which maximum run outs is $15 \mathrm{~km}$ from the top of the volcano, them were originated by the collapse of an eruptive column (Saucedo et al., 2005, 2010). In 2015, Colima volcano begin again his activity with an explosive event that produced a $10.5 \mathrm{~km}$ long block, ash flow and lava flows (Capra et al., 2016), its continuous activity is being permanently monitored (Global Volcanism Program, 2013). Situated between Guadalajara and Colima cities, the CV presents an approximately N-S orientation and, together with Cántaro and Nevado de Colima volcanoes?, compose the Colima Volcanic Complex (CVG). The CVC is located at the western part of Trans-Mexican Volcanic Belt (Figure 1a).

Most of the available $\mathrm{K}-\mathrm{Ar}$ and $\mathrm{C}^{14}$ radiometric age determinations performed in these volcanoes belong either to Nevado or Cántaro volcanic edifices (Luhr and Prestegaard, 1988; Robin et al., 1987; Komorowski et al., 1997; Macías et al., 2006; Cortés et al., 2005, 2010). Recently, Cortés (2015) reported 30 high quality radiometric dates carried out using ${ }^{40} \mathrm{Ar} /{ }^{39} \mathrm{Ar}$ systematic, which represents a major absolute age database for the CVC. This method, however, is only applicable for periods older than $50 \mathrm{ka}$ and better precision is reached to date volcanic units $>100 \mathrm{ka}$. So far, the $\mathrm{C}^{14}$ dating technique has traditionally been the most widely used method to date eruptions (charcoal found in deposits or paleosoils) occurred during Holocene and late Pleistocene. However, it should be noted that $\mathrm{C}^{14}$ dating is achieved on charcoal associated with organic matter charred by the hot pyroclastic flow deposits or lava flows (scarce) and buried paleosoils that provide maximum ages of the events. On the contrary, the archaeomagnetic dating method which now may be extend up to $14 \mathrm{ka}$ allows to date, in certain circumstances, the age of the erupted materials (Pavón-Carrasco et al., 2011, 2014). In other words, the radiocarbon systematics may date organic material but not directly a rock, while the archaeomagnetic method permits to get the absolute age for the lava flow cooling moment. In this study we intended to magnetically date some well constrained pyroclastic flow deposits and lava flows associated to the GVC in order to contribute to the absolute chronology of volcanic eruptions through paleomagnetic and rock-magnetic researches of rocks and pottery samples found into pyroclastic deposits. Although this novel dating methodology was already applied to Holocene lava flows (Pérez-Rodríguez et al., 2015; Böhnel et al., 2016; García-Quintana et al., 2016), this study is the first tentative to date pyroclastic deposits.

\section{Location and Description of sites}

Site San José del Carmen (SJC, Col 2 on Figure lb) is located at $19^{\circ} 28.071^{\prime} \mathrm{N}$ and $103^{\circ} 44.204^{\prime} \mathrm{W}$, with an altitude of $1350 \mathrm{~m}$. This outcrop presents a relatively thick pyroclastic flow deposit composed of embedded blocks into a yellow ash matrix (Figure 1). Here, we sampled a single block of gray andesite and phaneritic texture, with plagioclase and pyroxenes in a glassy matrix. The outcrop directly overlies the 3600-year-old debris avalanche deposit studied by Cortés et al. (2010). These authors considered this deposit as the result of an event caused by the collapse of the volcanic edifice which emplaced the debris avalanche deposit of Bezymianny type. The intrusion of a magmatic body that rise up through the main conduct inside the volcanic edifice causing its destabilization and subsequent collapse (Siebert et al., 1987). The de- 

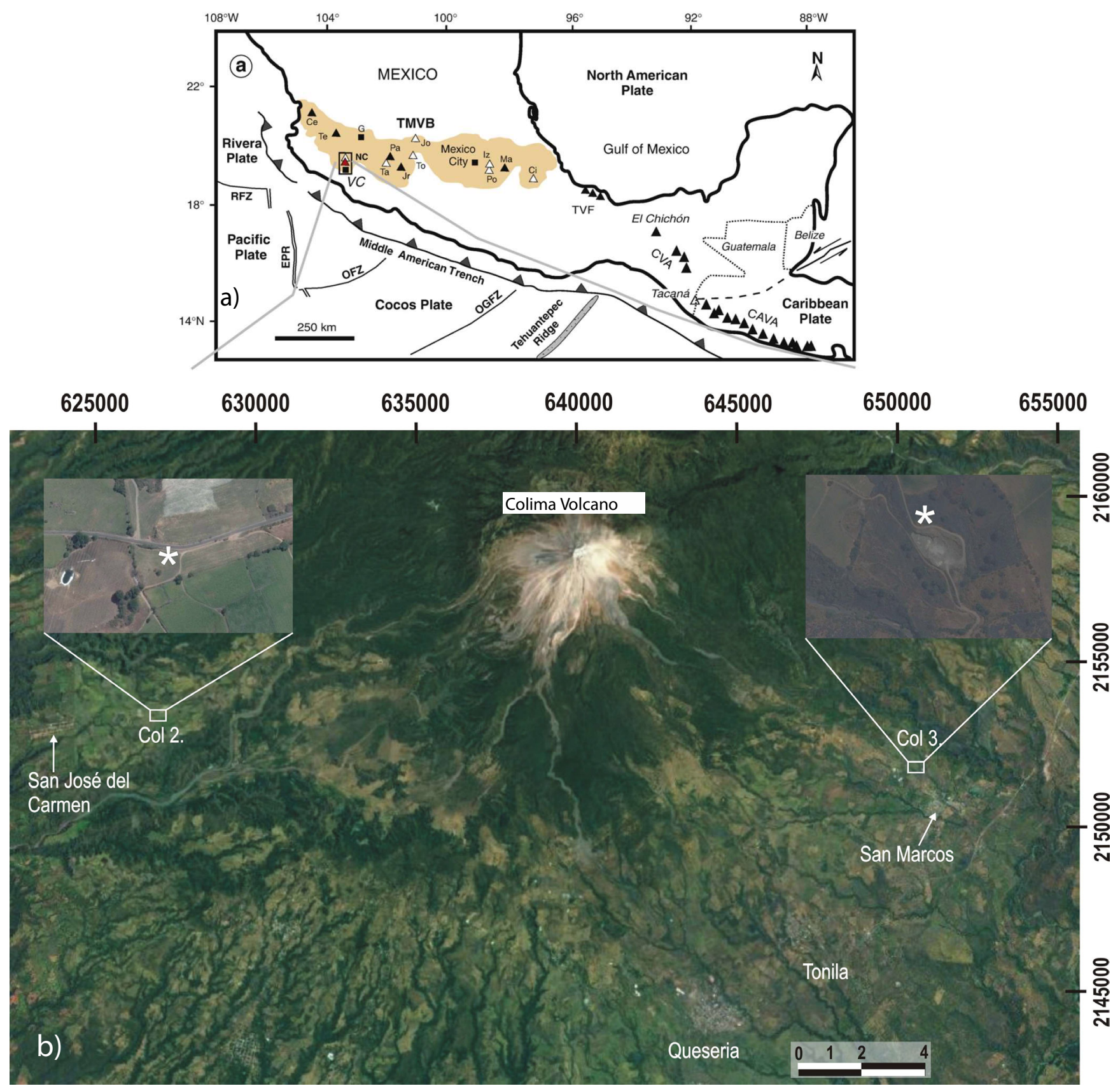

Figure 1 Location map of Colima Volcanic Complex on the western Trans-Mexican Volcanic belt (a) and setting details of San José del Carmen and San Marcos sites (b).

bris avalanche deposit is overlain by a $\sim 5 \mathrm{~m}$ thick lahar deposit with abundant pottery shards and charcoal. A sample of this charcoal was dated at $1940 \pm 90$ years BP (Cortés et al., 2010). The lahar deposit underlies a $\geq 40 \mathrm{~m}$ lake deposits sequence, which implies the presence of a temporary lake between the emplacement of the debris avalanche and the lahar deposition. The presence of pottery shards in the lahar reservoir suggests that human settlements in this region were affected by this catastrophic collapse of Colima volcano and their posterior flooding consequences. Ceramic fragments could belong to the first human groups (Capacha) settled in this region around 820 years 
BC (personal communication with the archaeologist Andrés Saúl Alcántara, National Institute of Anthropology and History).

In San Marcos (SM) town area (Col 3 on Figure $1 b, 19^{\circ} 27.334^{\prime} \mathrm{N}$ and $103^{\circ} 30.780^{\prime} \mathrm{W}$, altitude $1217 \mathrm{~m}$ ), at $1.5 \mathrm{~km}$ to the NW of the village, on the way to Juan Barragán, a 1.5 m thick yellow pyroclastic flow deposit composed by ash and pumice was sampled. The deposit contains abundant remnants of ceramics and charcoal fragments that were dated at $280 \pm 65$ years BP (Cortés, 2015). The age of these deposits and pottery contents indicates that this event was generated by a historical explosive eruption of the current Colima volcano building, which affected human settlements in the region.

This deposit overlies on a $6 \mathrm{~m}$ thick pyroclastic flow deposit, consisting of black andesite subrounded clasts and some blocks of pumice with abundant hornblende phenocrysts which are supported by a sandy matrix. In the basal part, the deposit contains abundant carbonaceous wood and a larger amount of slag blocks (diameters > $40 \mathrm{~cm}$ ). In contrast, the upper part contains blocks with sizes ranging from 10 to $30 \mathrm{~cm}$. These deposits overlie also a debris avalanche deposit that was dated at circa 28000 years BP and was associated with the Paleofuego volcano activity (former edifice of Colima volcano), which was defined as the San Marcos debris avalanche deposit (Roverato et al., 2011).

In order to estimate the magnetic anomalies associated to the studied sites, we compiled a composite aeromagnetic map (Figure 2) for the whole CVC area (López-Loera et al., 2011). The area is characterized by magnetic anomalies of different amplitudes and wavelengths that are associated with the GVG edifices and intrusive structures. The aeromagnetic map comprises the coordinates from $19^{\circ} 21^{\prime}$ to $19^{\circ} 40^{\prime} \mathrm{N}$ and from $103^{\circ} 28^{\prime}$ to $103^{\circ} \mathrm{W}$ covering an area of $1094 \mathrm{~km}^{2}(35.65 \mathrm{~km} x$ $30.68 \mathrm{~km})$. The San José del Carmen site is located on the NE margin of a monopolar and semicircular shape anomaly that presents magnetization intensity in the order of $35 \mathrm{nT}$ and an altitude of $1349 \mathrm{~m}$. The San Marcos site is located on an anomaly associated with an elongated low magnetic zone in a NE-SW direction, which shows a magnetization intensity of $-139 \mathrm{nT}$.

\section{Laboratory Methods}

Several rock-magnetic and paleomagnetic experiments were performed in order to estimate the magnetic mineralogy and to determine both the remanent magnetization characteristics and the absolute archeointensity of blocks and pottery samples.

Continuous thermomagnetic curves up to $600^{\circ} \mathrm{C}$ were recorded using an AGICO - MFK1B Kappabridge while remanence measurements were performed with a JR6a spinner magnetometer. A LDA 3 alternating field demagnetizer up to 95 mT and a ASC TD48 dual chamber thermal demagnetizer (provided with field coils) were used to isolate the primary remanent magnetization. The Thellier variant (Thellier and Thellier, 1959; Coe et al., 1978) for absolute paleointensity measurements was employed in this study. The magnetic field laboratory was set to $45 \mu \mathrm{T}$, with a 0.5 $\mu \mathrm{T}$ precision. Thirteen temperature steps, starting from $150^{\circ} \mathrm{C}$ until $560^{\circ} \mathrm{C}$, were distributed throughout the whole experiments and the control heatings (so-called pTRM checks) them were performed after every second temperature steps. In case of the pottery samples, they were divided into six fragments and oriented in salt pellets with six different positions $\pm X, \pm r, \pm Z$ to reduce the magnetic anisotropy effect (Morales et al., 2009, 2012). Cooling rate experiments were performed following a modified procedure described by Chauvin et al. (2000) (i.e. Morales et al., 2009). Three consecutive cooling velocities (fast, slow, fast), at the highest temperature were used to estimate the cooling rate effect, and to correct the absolute (raw) intensity values. The duration of slow (natural) cooling was about $7 \mathrm{~h}$. 

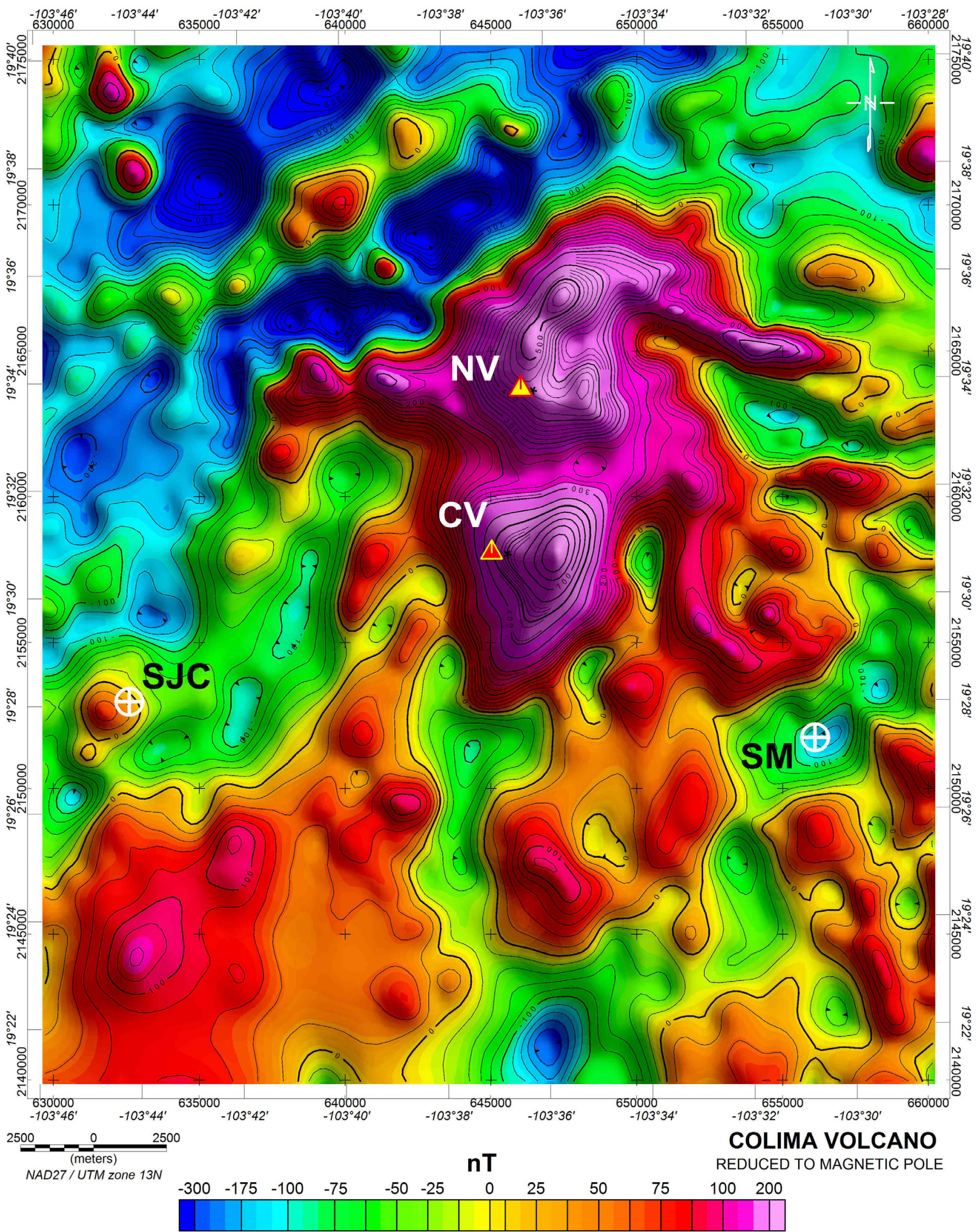

Figure 2 Magnetic anomaly distribution map along the Colima Volcano showing magnetic structures around the studied sites. 


\section{Main results and concluding remarks}

\subsection{SAN JOSÉ DEL GARMEN SITE}

The continuous thermomagnetic curve recorded for this site (Figure 3a) indicates that there was an almost pure magnetite or some extreme member of titanomagnetite with very low titanium content inasmuch as the Curie temperature (determined using the method of Prévot et al., 1983) is close to $565^{\circ} \mathrm{C}$. The heating and cooling curves are reasonably reversible, especially between 350 and $570^{\circ}$ C. No confirmed evidence of a second ferromagnetic phase was detected. In contrast, magnetic cleaning experiments evidenced a very strong secondary component, probably due to a lightning effect, which could be removed applying $30 \mathrm{mT}$ peak alternating field. The remanent magnetization characteristics were defined between 35 and $90 \mathrm{mT}$ (Figure 3b). The magnetic treatment using the alternating field proved to be efficient and able to remove almost completely the overprinted remanent magnetization considering the paleomagnetic directions are quite well defined (Figure 3c). The mean characteristic paleodirection is supported by 7 of 9 collected cores; Inc $=$ $39.6^{\circ}$ (inclination), $\mathrm{Dec}=350.7^{\circ}$ (declination), with precision parameters $\mathrm{a}_{95}=2.2^{\circ}$ and $\mathrm{k}=633$ (Table 1B). Due to the presence of strong secondary magnetization, absolute paleointensity experiments are meaningless.

\subsection{SAN MARCOS SITE}

The magnetic mineralogy of SM blocks is very complex as a result of two ferromagnetic phases that were detected during heating phase, in contrast only magnetite seems to be present on the cooling curve. The low temperature phase with a Curie point about $320^{\circ} \mathrm{C}$ may correspond to titanomaghemites (Figure 4a) which are characterized by a major thermal instability. Seven samples were subjected to alternating field demagnetization procedure. The samples basically show univectorial remanent magnetization although they were accompanied with small viscous overprint from 10 to $15 \mathrm{mT}$. Only $60 \%$ of magnetization was removed after applying 95 peak alternating field (Figure 4b) which corroborate that the remanence is dominated by small pseudo-single-domain grains. The mean direction of the characteristic site supported by 6 samples is $\mathrm{Inc}=55.1^{\circ}$ and $\mathrm{Dec}=229.4^{\circ}$, with precision parameters $\mathrm{a}_{95}=2.1^{\circ}$ and $\mathrm{k}=1039$ (Figure 4c and Table 1A). It is obvious that this

\section{SITE SAN JOSE DEL CARMEN}
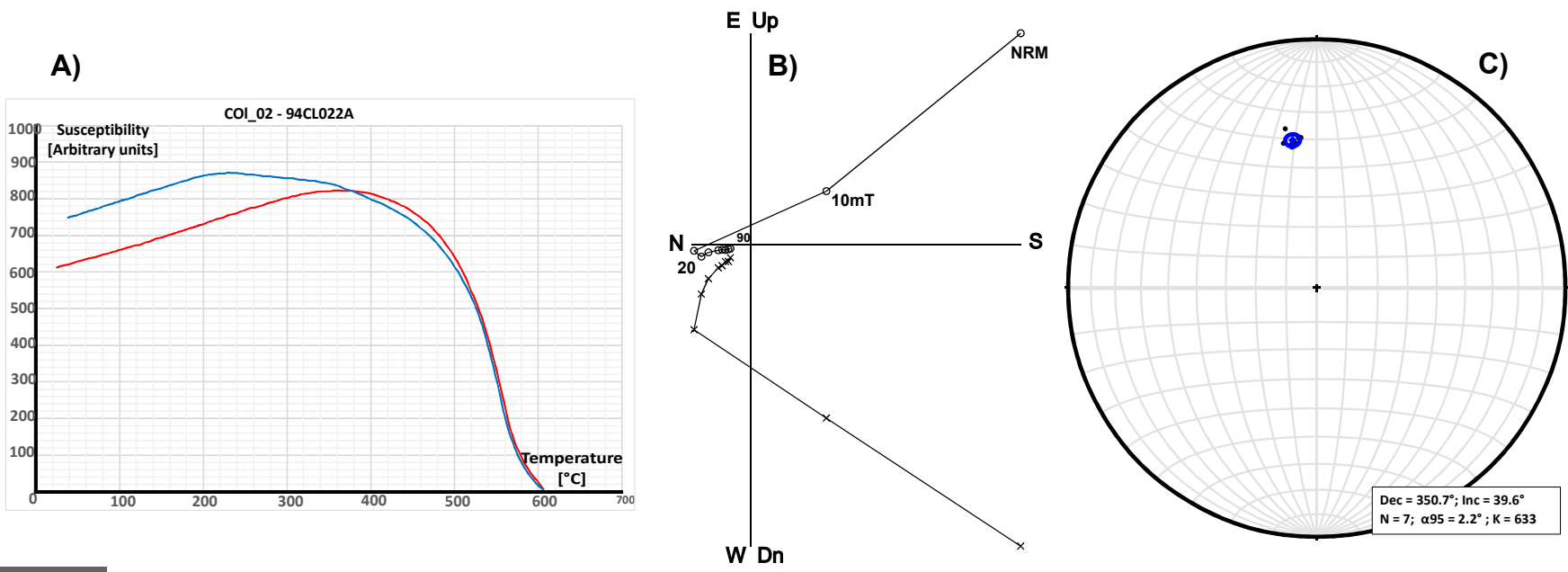

Figure 3 Summary of rock-magnetic and paleomagnetic experiments for San José del Carmen pyroclastic lava flow: a) Susceptibility vs. temperature curve with heating (red) and cooling (blue) cycle, b) orthogonal vector plot of alternating field demagnetization and c) equal-area projection of characteristic mean paleodirections. 
Table 1. Paleodirection and paleointensity results for Colima volcanic units and oriented pottery fragment: A) Results of site and fragment mean paleodirections for Colima volcanic units and oriented pottery fragment. Site: Names of the sample (SJC-San José del Carmen, SM-San Marcos); $\mathbf{n} / \mathrm{N}: \mathbf{n}$ is the number of samples used in mean calculation while $\mathbf{N}$ refers to the total number of samples per site; Inc and Dec: mean inclination and declination; $\mathrm{k}$ and a95: precision parameter and $95 \%$ confidence angle.

B) paleointensity results at sample level. $n$ : the number of heating steps used for the intensity determination; $T_{\min }-T_{\max }:$ the temperature interval of intensity determination; $B(c o r r)$ : paleointensity value corrected for cooling rate effect; $\gamma$ is the angle between the direction of ChRM and that one of the composite magnetization equal to $\operatorname{NRM}(T)$ if $\operatorname{CRM}(T)$ is zero. It was obtained from the orthogonal plots derived from the Thellier paleointensity experiments; $f$ : the fraction of NRM used for intensity determination; g: the gap factor; Q: the quality factor as defined by Coe et al. (1978).

A)

\begin{tabular}{|c|c|c|c|c|c|}
\hline Site & $\mathbf{n} / \mathbf{N}$ & Inc $\left(^{\circ}\right)$ & $\operatorname{Dec}\left(^{\circ}\right)$ & $\mathbf{a}_{\mathbf{9 5}}\left(^{\circ}\right)$ & $\mathbf{K}$ \\
\hline SJC Lava & $7 / 8$ & 39.6 & 350.7 & 2.2 & 633 \\
\hline SM Lava & $6 / 8$ & 55 & 229.4 & 2.1 & 1039 \\
\hline SM Pottery & $5 / 5$ & 27.3 & 4.4 & 2.6 & 677 \\
\hline
\end{tabular}

B)

\begin{tabular}{|c|c|c|c|c|c|c|c|c|c|}
\hline Site & Sample & n & $T_{\min }-T_{\max }$ & $\begin{array}{c}\text { B(corr) } \\
\text { (CR) }\end{array}$ & sH & g & f & g & $\mathbf{q}$ \\
\hline & & & $\left({ }^{\circ} \mathbf{c}\right)$ & $(\mathrm{mT})$ & & & & & \\
\hline $\begin{array}{c}\text { San } \\
\text { Marcos }\end{array}$ & 99C067A & 11 & $200-560$ & 50.9 & 3.4 & 3.3 & 0.93 & 0.83 & 18.9 \\
\hline \multirow[t]{7}{*}{ Pottery } & $99 \mathrm{C} 067 \mathrm{~A}$ & 10 & $200-540$ & 46.9 & 2.8 & 3.7 & 0.76 & 0.81 & 14.6 \\
\hline & $99 \mathrm{C} 068 \mathrm{~A}$ & 9 & $250-540$ & 48.4 & 3.4 & 3.8 & 0.73 & 0.8 & 11.4 \\
\hline & $99 \mathrm{C} 068 \mathrm{~B}$ & 10 & $200-540$ & 53.3 & 3.6 & 5.1 & 0.69 & 0.77 & 8.6 \\
\hline & $99 \mathrm{C} 070 \mathrm{~A}$ & 10 & $200-540$ & 51.6. & 3.3 & 2.9 & 0.73 & 0.79 & 14.1 \\
\hline & 99C071A & 9 & $250-540$ & 50.8 & 3.6 & 4.2 & 0.74 & 0.81 & 10.6 \\
\hline & & & Mean $=$ & 50.3 & & & & & \\
\hline & & & s.d. $=$ & 2.3 & & & & & \\
\hline
\end{tabular}

direction has no geomagnetic significance and should be attributed to the block moving after the emplacement of the pyroclastic flows during the cooling process.

More of three magnetic phases may be present in the pottery sample (Figure 5a). According to the susceptibility $v$ s. temperature plot, they are intercalated in the SM pyroclastic flow deposit. LowTi titanomagnetite, magnetite, and probably also hematite, co-exist in this ceramic, overall showing a high reversibility and thus a relatively high thermal stability. Hematite seems to have very minor contribution in magnetizations, since the rema- nence was almost completely removed at $95 \mathrm{mT}$ alternating fields (Figure 5b). The viscous remanent magnetization is also present here but it was easily removed at $10 \mathrm{mT}$. The mean direction of the characteristic site is $\mathrm{Inc}=27.3^{\circ}, \mathrm{Dec}=4.4^{\circ}$ with precision parameters $\mathrm{a}_{95}=2.6^{\circ}$ and $\mathrm{k}=677$ (Figure 5c).

As archeointensity experiments were concerned, the Arai plots for the SM blocks present a wellmarked concave-up behavior and no linearity was observed on the whole segment (Figure 6). Thus no positive determinations were obtained for this single block. In contrast, the pottery sample yielded/ 


\section{SITE SAN MARCOS (LAVA)}

A)

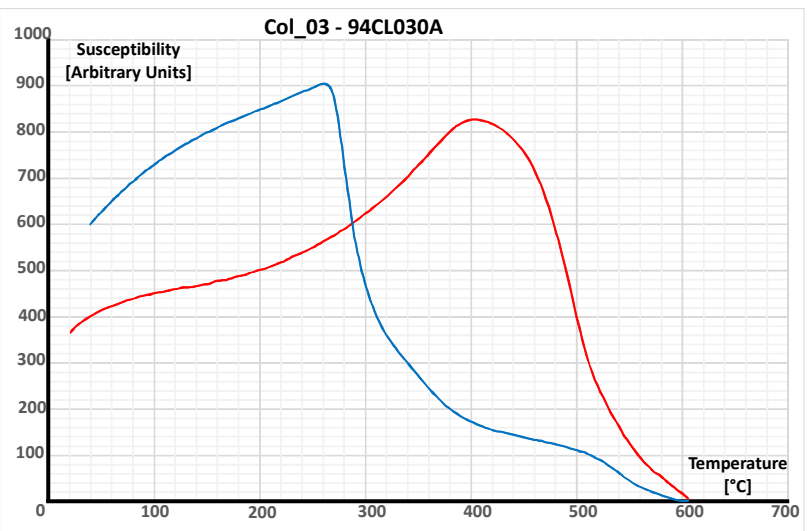

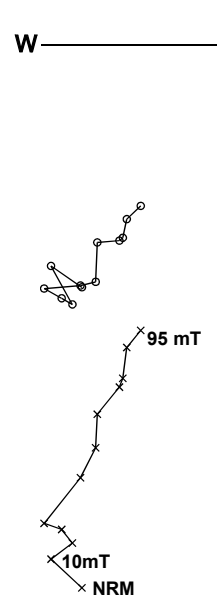

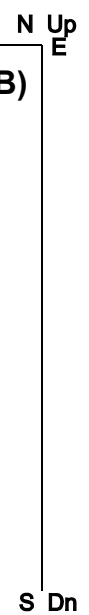

C)

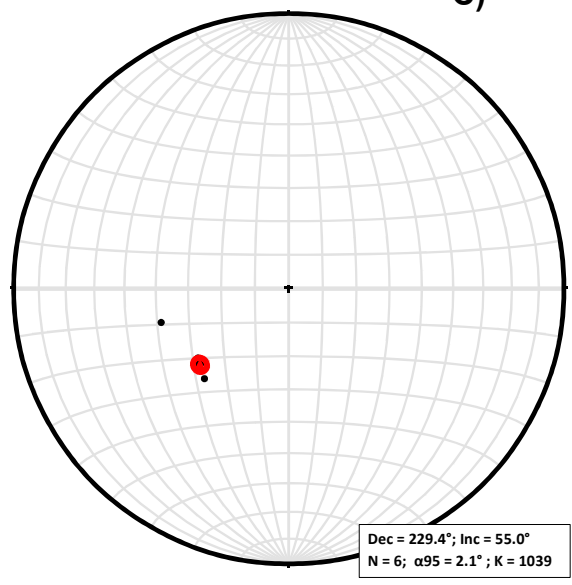

Figure 4 Summary of rock-magnetic and paleomagnetic experiments for San Marcos pyroclastic lava flow: a) Susceptibility vs. temperature curve with heating (red) and cooling (blue) cycle, b) orthogonal vector plot of alternating field demagnetization and c) equal-area projection of characteristic mean paleodirections.

\section{SITE SAN MARCOS (POTTERY)}
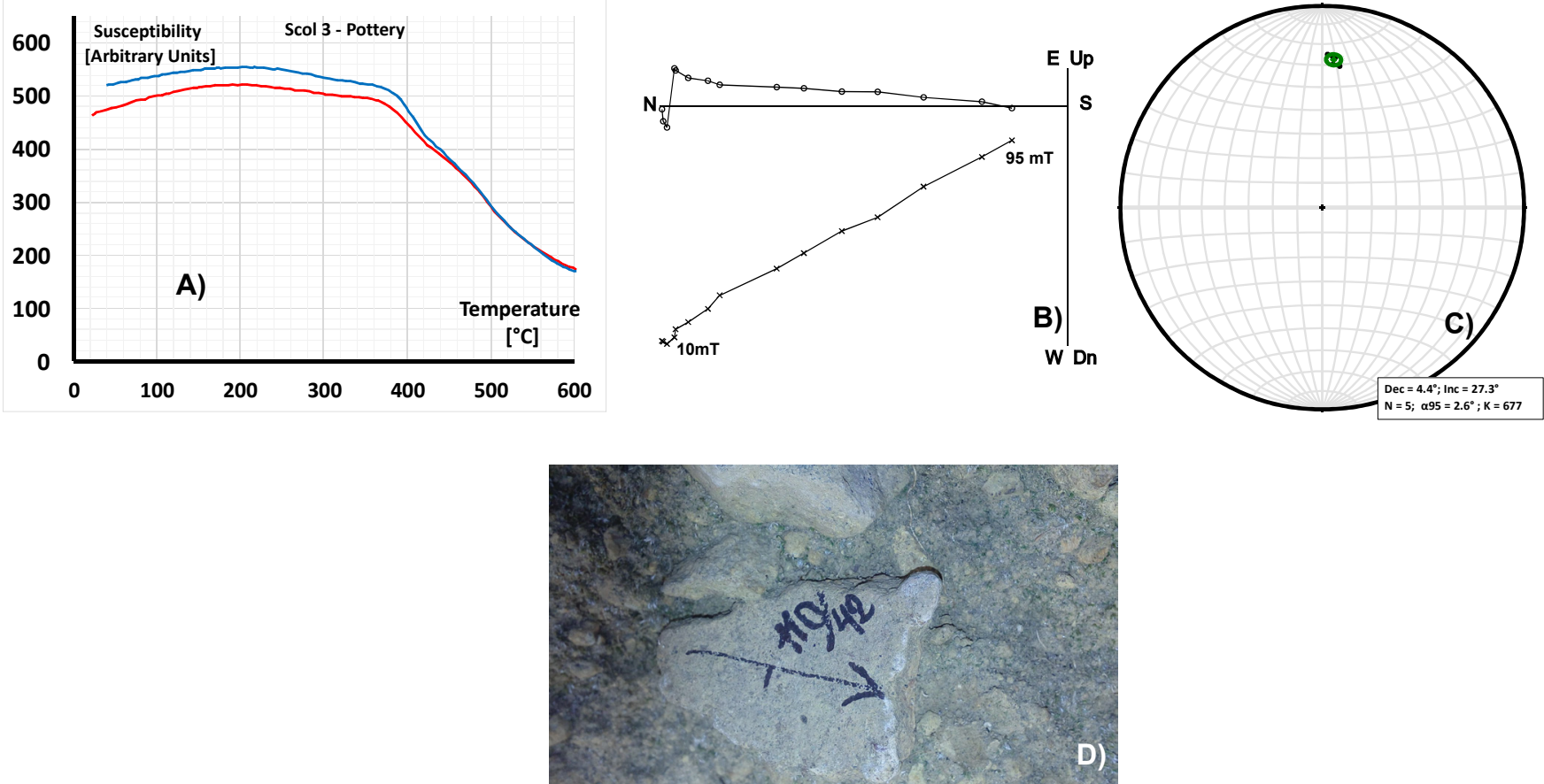

Figure 5 Summary of rock-magnetic and paleomagnetic experiments for oriented pottery samples intercalated into San Marcos pyroclastic lava flow deposits: a) Susceptibility vs. temperature curve with heating (red) and cooling (blue) cycle, b) orthogonal vector plot of alternating field demagnetization, c) equal-area projection of characteristic mean paleodirections and d) pottery fragment intercalated in pyroclastic flow. 
shows a very high technical quality determination. These specimens exhibited almost linear behavior in both the Arai and associated Zijderveld plots while the control heatings were also positive (within the $10 \%$ ). Small secondary viscous components may be present but easily removed at first temperature stages, between $250^{\circ} \mathrm{C}$ and $300^{\circ} \mathrm{C}$. The quality parameters (Coe et al., 1978) match the commonly adopted criteria and the SCAT parameter was accomplished (Shaar and Tauxe, 2013). All analyzed samples show reliable absolute intensity determinations (Table 1B). For these samples, the NRM (Natural Remanent Magnetization) fraction $f$ was used to determinate the ranges between
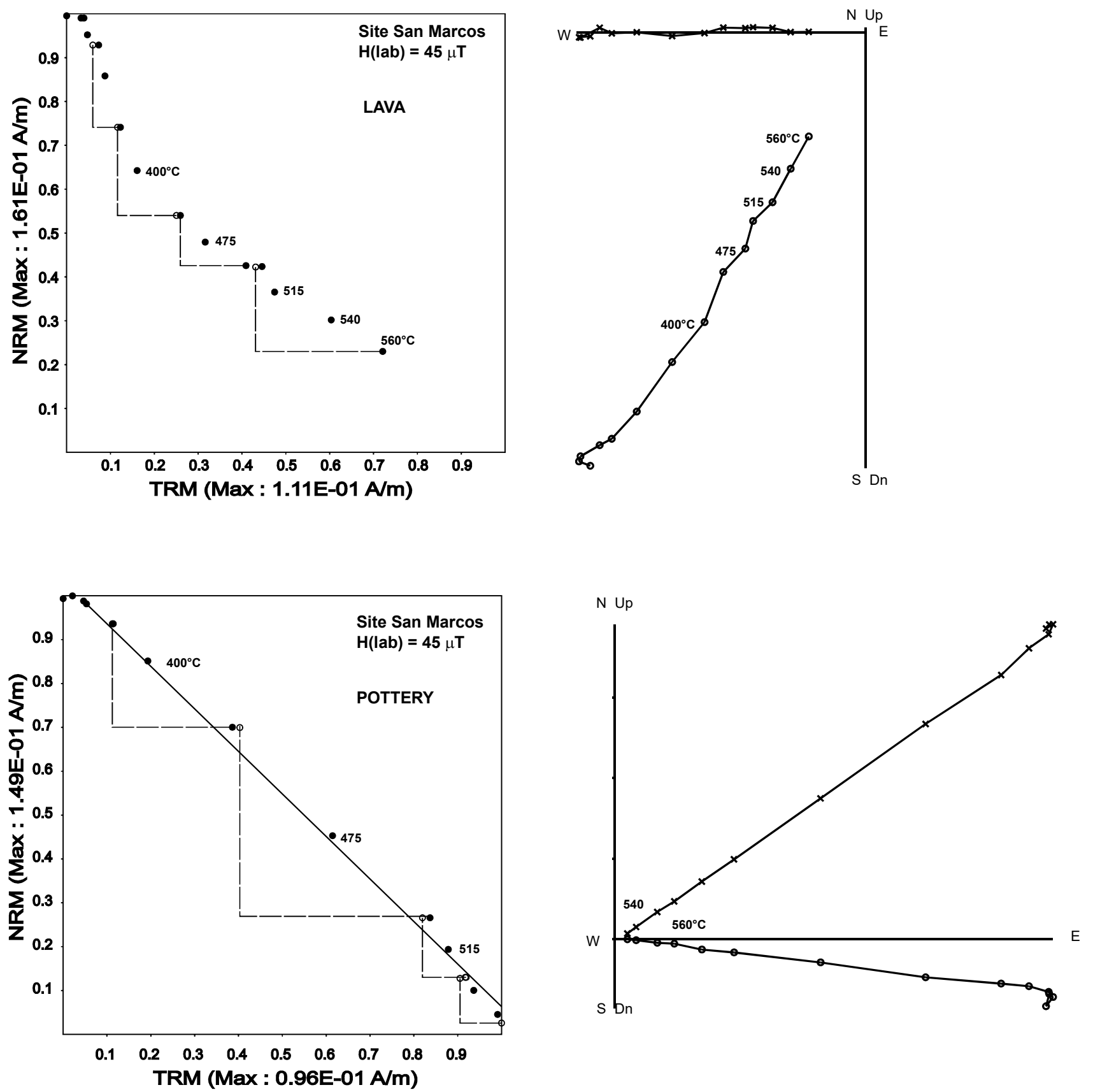

Figure 6 Examples of NRM-TRM curves also known as Arai plots and associated orthogonal vector plots for San Marcos lava flow block and ceramic fragment (see text for more details). 
0.69 and 0.93 and the quality factor $q$ from 8.6 to 18.9; were generally greater than 10 . The angle $\gamma$ between the direction of ChRM (characteristic remanent magnetization) and that one of the composite magnetization equal to $\operatorname{NRM}(T)$ if $\operatorname{CRM}(T)$ (CRM refers to chemical remament magnetization), obtained from the orthogonal plots derived from the Thellier paleointensity experiments, was found always below 5 degrees. The cooling rate correction slightly reduced the standard deviation of the mean intensities. The individual archaeointensity values obtained in this study ranged from 46.9 to $53.3 \mu \mathrm{T}$. The mean archeointensity obtained from five specimens was $50.3(2.3) \mu \mathrm{T}$, which is slightly higher than the present day geomagnetic field strength for the Colima area.

\subsection{MAGNETIC DATING}

The SHA.DIF.14K, global geomagnetic prediction model (Pavón-Carrasco et al., 2014), is now successfully used as reliable dating tool mainly for archaeomagnetic material (Morales et al., 2016, Terán-Guerrero et al., 2016). Furthermore, recent researches proved its usefulness to precisely date several volcanic rocks along the Trans-Mexican Volcanic Belt formed during the Holocene (Pérez-Rodríguez et al., 2015; Böhnel et al., 2016; García-Quintana et al., 2016). For the case of blocks contained in pyroclastic flow deposits produced by Colima volcano, a successful absolute age determination was achieved for two sites (Figure 7 and 8). At the SJC site, the block generates two possible time intervals that are between 1776

\section{SITE SAN JOSE DEL CARMEN}
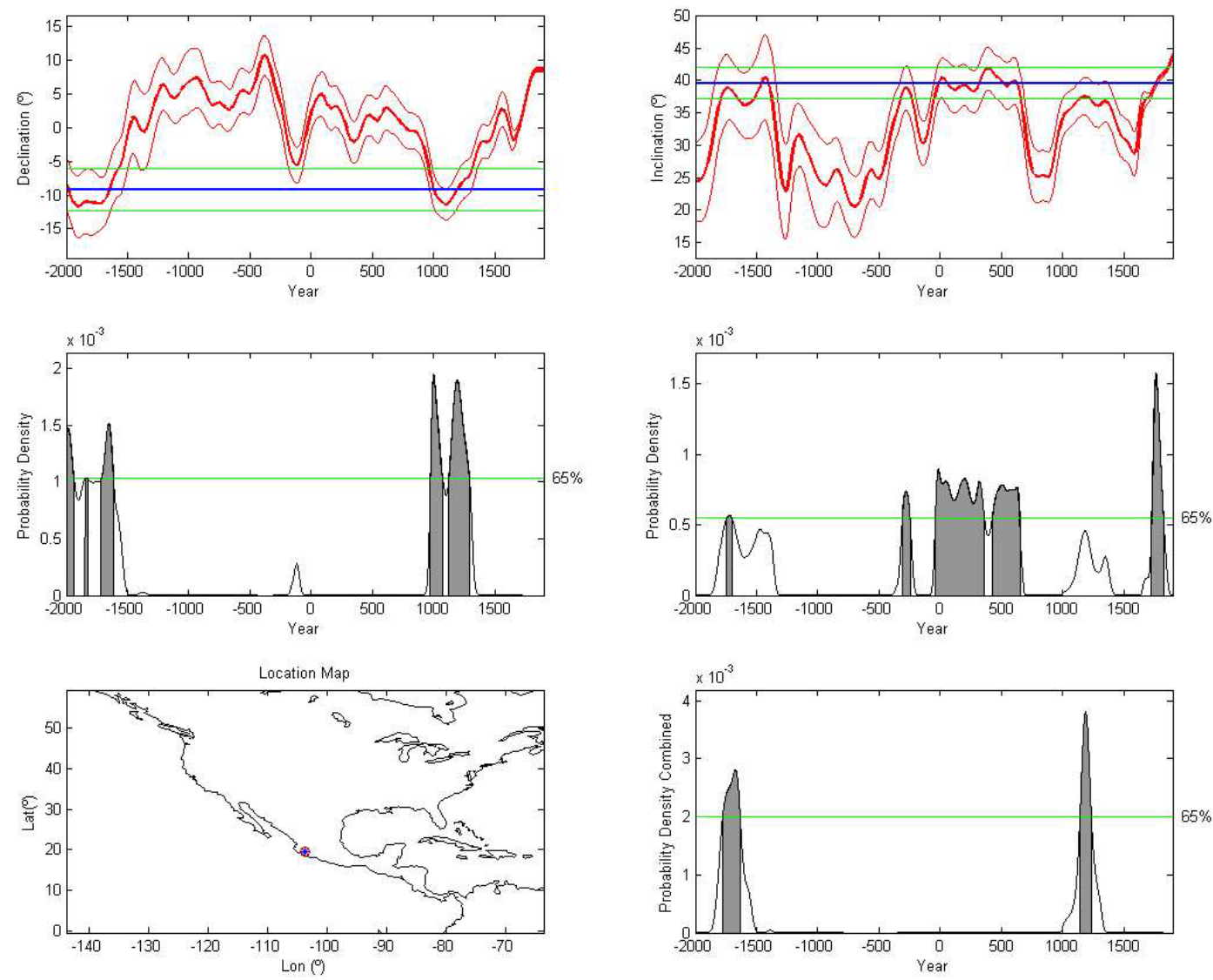

Dating : CLO2

Combining Probability Density Functions Threshold $=0.0020061$ (Confidence $=65 \%)$ Between $\mathrm{t}=2000 \mathrm{BC}$ and $1900 \mathrm{AD}$

[1776BC $1634 \mathrm{BC}]$ [1143AD 1236AD]

Figure 7 Magnetic dating of San José del Carmen lava block using Matlab tool of Pavón-Carrasco et al. (2014) based on declination and inclination. 


\section{SITE SAN MARCOS}
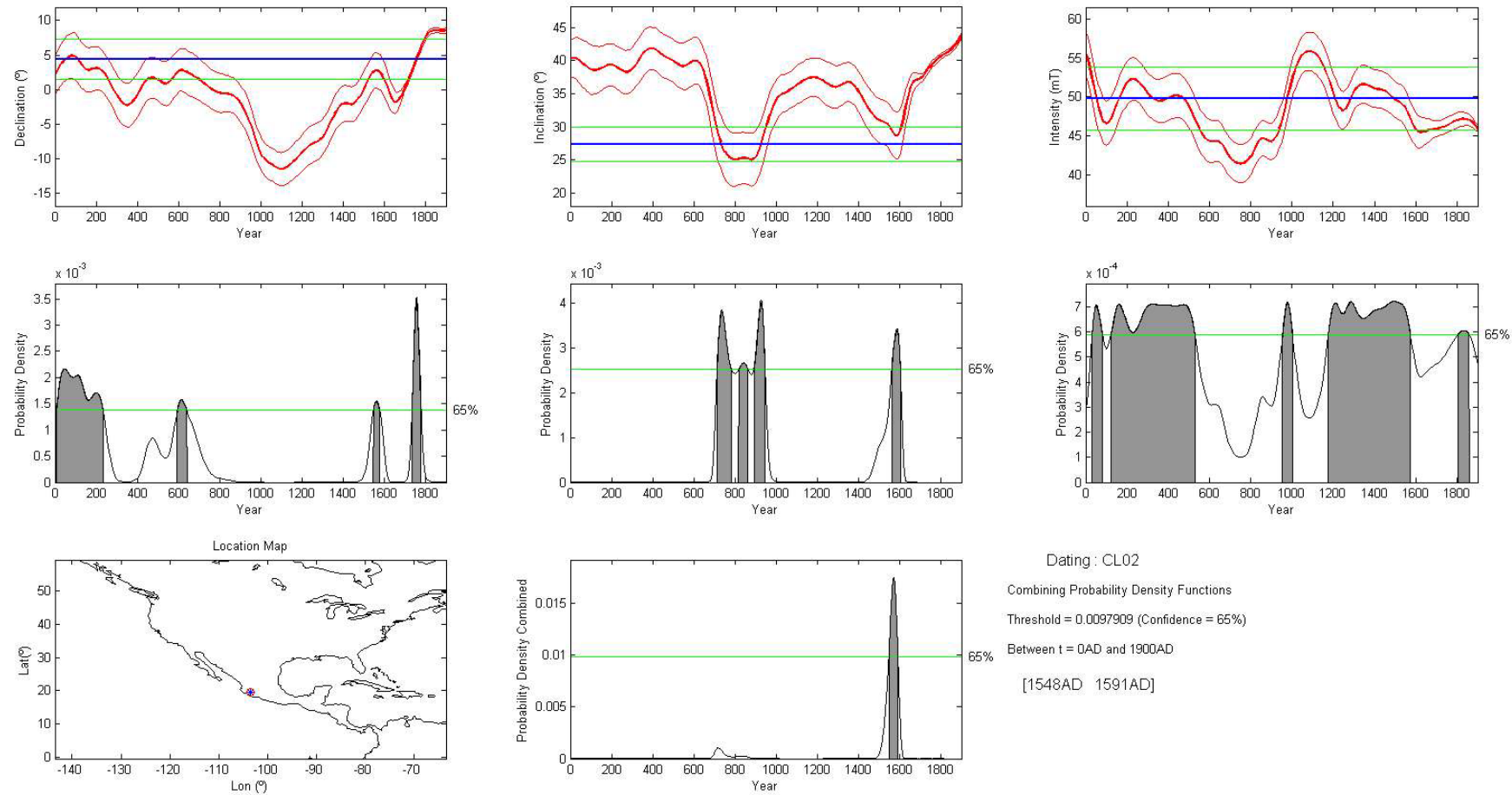

Figure 8 Magnetic dating of San Marcos site lava block using Matlab tool of Pavón-Carrasco et al. (2014) based on declination, inclination and absolute intensity.

- $1634 \mathrm{BC}$ and $1143-1236 \mathrm{AD}$. The first interval, however, determined on the basis of the magnetic inclination and declination, seems to be the most appropriate age for the deposit because it correlated within the uncertainties range with the previous radiocarbon date of the site. Thus, an interval between $1776-1634 \mathrm{BC}$ is considered as the best estimate for the emplacement time at the SJC pyroclastic flow deposit. The magnetic dating of the SM site is supported by full geomagnetic vector (directions and intensity) parameters retrieved from the pottery fragment incorporated by the pyroclastic flow deposit. A unique time interval going from 1548 to $1591 \mathrm{AD}$ is the most probable age estimation for the eruption. Therefore, the result obtained is in reasonably good agreement with the available radiometric dating.

\section{Conclusion}

The application of the archaeomagnetic dating method, using the SHA.DIF.14K model for pyroclastic flow deposit produced by Colima volcano, shows positive results due to the obtained ages were in reasonably good agreement with the available radiometric dates. It is worth noting that the ages obtained by the $\mathrm{C}^{14}$ method represent the age during which the organic matter was charred and later incorporated within the soil formation and it does not necessarily correspond to the age of the rock studied. Instead, the age obtained here using the archaeomagnetic method corresponds to the precisely moment of the emplacement for the pyroclastic flow and its posterior rock cooling. These processes and time elapsed between the pyroclastic flow emplacement and charcoal in the paleosoil could indicate the small difference ob- 
served between both ages. Therefore, the archaeomagnetic dating method provides a more accurate age determination for both the cooling moment of the rock and the eruption timing. Due to the time span involved, the archaeomagnetic dating method has a significant advantage compared to the radiometric methods of $\mathrm{K} / \mathrm{Ar}$ and ${ }^{40} \mathrm{Ar} /{ }^{39} \mathrm{Ar}$ which are applied to older time span (> $50 \mathrm{ka})$.

\section{Acknowledgements}

The authors are thankful for the financial support provided by UNAM-PAPIT IN101717 while some partial funds were provided by CONAGYT $\mathrm{n}^{\circ}$ 252149. MC is grateful for the financial support given by UNAM-DGAPA-PAPIIT IA106517.

\section{References}

Böhnel, H., Pavón-Carrasco, FJ., Sieron, K., Mahgoub, A.N., 2016, Palaeomagnetic dating of two recent lava flows from Ceboruco volcano, western Mexico: Geophysical Journal International, 207(2), 1203-1215.

Capra, L., Macías, J.L., Cortés, A., Dávila, N., Saucedo, R., Osorio-Ocampo, S., Arce, J.L., Gavilanes-Ruiz, J.G., Corona-Chávez, P., García-Sánchez, L., Sosa-Ceballos, G., Vázquez, R., 2016, Preliminary report on the July 10-11, 2015 eruption at Volcán de Colima: Pyroclastic density currents with exceptional runouts and volume: Journal of Volcanology and Geothermal Research, 310, 39-49.

Chauvin, A., García, A., Lanos, Ph., Laubenheimer, F., 2000, Paleointensity of the geomagnetic field recovered on archaeomagnetic sites from France: Physics of the Earth and Planetary Interiors, 120, 111-136.

Coe, R.S., Grommé S., Mankinen, E.A., 1978, Geomagnetic paleointensities from radiocarbon-dated lava flows on Hawaii and the question of the Pacific nondipole low: Journal of Geophysical Research, 83, 1740-1756.

Cortés, A., 2015, Historia eruptiva del volcán

Nevado de Colima y su evolución dentro del Complejo Volcánico, de Colima (GVC): México, Universidad Nacional Autónoma de México, Ph.D. Thesis, 186 p.

Cortés, A., Garduño, V.H., Macías, J.L., NavarroOchoa, C., Komorowski, J.C., Saucedo, R., Gavilanes, J.C., 2010, Geologic mapping of Colima volcanic complex (Mexico) and implications for hazard assessment, in Groppelli, G., Viereck-Goette, L. (eds.), Stratigraphy and Geology of Volcanic Areas: Geological Society of American Special Paper, 464, 1-16.

Cortés, A., Garduño, V.H., Navarro-Ochoa, C., Komorowski, J.C., Saucedo, R., Macías, J.L., Gavilanes, J.C., 2005, Carta Geológica del Complejo Volcánico de Colima: México, D.F., Universidad Nacional Autónoma de México, Instituto de Geología, Cartas Geológicas y Mineras 10, scale 1:100,000, 1 sheet, $37 \mathrm{p}$.

De la Cruz-Reyna, S., 1993, Random patterns of occurrence of explosive eruptions at Colima Volcano: Journal of Volcanology and Geothermal Research, 5(1-2), 51-68.

García-Quintana, A., Goguitchaichvili, A., Morales, J.M., Cervantes-Solano, S. OsorioOcampo,J., Macías, L., Urrutia-Fucugauchi, J., 2016, Datación magnética de rocas volcánicas formadas durante el Holoceno: caso de flujos de lava alrededor del Lago de Pátzcuaro (campo volcánico MichoacánGuanajuato): Revista Mexicana de Ciencias Geológicas, 33(2), 209-220.

Global Volcanism Program, 2013, Colima (341040) (online): in Volcanoes of the World, v. 4.5.6. Venzke, E. (ed.), Smithsonian Institution, available at <http://volcano. si.edu/volcano.cfm?vn $=341040>$, accessed 05/03/2017.

Komorowski, J.C., Navarro, C., Cortés, A., Saucedo, R., Gavilanes, J.C., 1997, The 
Colima Complex: Quaternary multiple debris avalanche deposits, historical pyroclastic sequences (pre-1913, 1991 and 1994), in IAVCEI, Plenary Assembly, Fieldtrip guidebook: Guadalajara, Jalisco: Puerto Vallarta, México, Gobierno del Estado de Jalisco, Secretaría General, Unidad Editorial, 1-38.

López-Loera, H., Urrutia-Fucugauchi, J., AlvaValdivia, L., 2011, Estudio aeromagnético del complejo volcánico de Colima, occidente de México - implicaciones tectónicas y estructurales: Revista Mexicana de Ciencias Geológicas, 28(3), 349-370.

Luhr, J.F., Carmichael, I.S.E., 1990, Geology of Volcan de Colima. Editor: Universidad Nacional Autónoma de México, Instituto de Geología, Boletín, 107, 101 pp.

Luhr, J.F., Prestegaard, K.L., 1988, Caldera formation at Volcán de Colima, México, by a large Holocene volcanic debris avalanche: Journal of Volcanology and Geothermal Research, 35, 335-348.

Macías, J.L., Saucedo, R., Gavilanes, J.C., Varley, N., Velasco-García, S., Bursik, M.I., VargasGutiérrez, V., Cortés, A., 2006, Flujos piroclásticos asociados a la actividad explosiva del Volcán de Colima y perspectivas futuras: GEOS, 25(3), 340-351.

Morales, J., Goguitchaichvili A., Acosta G., González-Morán T., Alva-Valdivia L.M., Robles-Camacho, J., HernándezBernal, M.S., 2009, Magnetic properties and archeointensity determination on Pre Columbian pottery from Chiapas, Mesoamerica. Earth Planets Space, 61, 83-91.

Morales, J., Goguitchaichvili, A., Aguilar-Reyes, B., Pineda, M., Carvallo, C., Baramendi, L., Hernández, G., Oliveros, A., 2012, A Detailed Rock-Magnetic and Archeointensity Investigation on some pottery Relics and Burned Floors from Tzintzuntzan Archeological Site, Western Mesoamerica, Geoarchaeology, 27(6), 521-537.
Morales, J., del Sol Hernández-Bernal, M., Goguitchaichvili, A., Punzo-Díaz, J.L., 2016, An integrated magnetic, geochemical and archeointensity investigation of casting debris from ancient metallurgical sites of Michoacán, Western Mesoamerica. Studia Geophysica et Geodaetica, 61(2), 290-309.

Pavón-Carrasco, F.J., Osete, M.L., Torta, J.M., Santis, A.D., 2014, A geomagnetic field model for the Holocene based on archaeomagnetic and lava flow data: Earth and Planetary Science Letters, 388, 98-109.

Pavón-Carrasco, FJ., Rodríguez-Gonzáles, J., Osete, M.L., Torta, J.M., 2011, A Matlab tool for archaeomagnetic dating: Journal of Archaeological Science, 32(8), 408-419.

Pérez-Rodríguez, N., Morales-Contreras, J., García-Tenorio, F., Gogishaishvili, A., 2015, Fechamiento arqueomagnético de las últimas tres erupciones plinianas del volcán Popocatépetl: Proceedings São Paulo, Brasil, Latinmag Letters, Special Issue, 6, C1 1, 1-7. Prévot, M., Mankinen E.A., Gromme S.C., Coe, R.S., 1983, How the geomagnetic field vector reverses polarity: Nature, 316(6025), 230-234.

Robin, J., Mossand, P., Camus, G., Cantagrel, J.M., Gourgand, A., Vincent, P.M., 1987, Eruptive history of the Colima volcanic complex (México): Journal of Volcanology and Geothermal Research, 31, 99-113.

Roverato, M., Capra, L., Sulpizio, R., Norini, G., 2011, Stratigraphic reconstruction of two debris avalanche deposits at Colima Volcano (Mexico): Insights into pre-failure conditions and climate influence: Journal of Volcanology and Geothermal Research, 207, 33-46.

Saucedo, R., Macías, J.L., Gavilanes, J.C., Arce, J.L., Komorowski, J.G., Gardner, J.E., ValdezMoreno, G., 2010, Eyewitness, stratigraphy, chemistry, and eruptive dynamics of the 1913 Plinian eruption of Volcán de Colima, México: Journal of Volcanology and Geothermal Research, 191(3-4), 149-166. 
Saucedo, R., Macías, J.L., Sheridan, M.F., Bursik, M.I., Komorowski, J.C., 2005, Modeling of pyroclastic flow of Colima Volcano, Mexico: implications for hazard assessment: Journal of Volcanology and Geothermal Research, 139, 103-115.

Shaar, R., Tauxe, L., 2013, Thellier GUI: An integrated tool for analyzing paleointensity data from thellier-type experiments: Geochemistry Geophysics Geosystems, 14, 677-692.

Siebert, L., Glicken, H., Ui, T., 1987, Volcanic hazards from Bezymianny- and Bandaitype eruptions: Bulletin of Volcanology, 49, 435-459.
Terán-Guerrero, A., Goguitchaichvili, A., EsparzaLópez, R., Morales, J., Elguera, J.R., Soler, A. M., Cárdenas, E., Urrutia-Fucugauchi, J., 2016, A detailed rock-magnetic and archaeomagnetic investigation on wattle and daub building (Bajareque) remains from Teuchitlán tradition (NW Mesoamerica): Journal of Archaeological Science: Reports, 5, 564-573.

Thellier, E., Thellier, O., 1959, Sur l'intensité du champ magnétique terrestre dans le passé historique et géologique: Annals of Geophysics, 15, 285-376. 